\title{
The Impact of Obesity on the Association between Vitamin D Deficiency and Cardiovascular Disease
}

\author{
Stavroula A. Paschou 1,2,*®D, Marinos Kosmopoulos ${ }^{3}$, Ilias P. Nikas ${ }^{2}{ }^{\oplus}$, Michael Spartalis ${ }^{4}$, \\ Evanthia Kassi ${ }^{5}$, Dimitrios G. Goulis ${ }^{6}$, Irene Lambrinoudaki ${ }^{7}$ and Gerasimos Siasos ${ }^{8}$ \\ 1 Division of Endocrinology and Diabetes, Aghia Sophia Hospital, Medical School, National and Kapodistrian \\ University of Athens, 11527 Athens, Greece \\ 2 School of Medicine, European University Cyprus, 2404 Nicosia, Cyprus; i.nikas@euc.ac.cy \\ 3 Department of Medicine, Division of Cardiology, School of Medicine, University of Minnesota, \\ Minneapolis, MN 55455, USA; marinos.kosmopoulos@outlook.com.gr \\ 4 Division of Cardiology, Onassis Cardiac Surgery Centre, 17674 Athens, Greece; msparta@med.uoa.gr \\ 5 Department of Biological Chemistry, Medical School, National and Kapodistrian University of Athens, \\ 11527 Athens, Greece; evakassis@gmail.com \\ 6 Department of Obstetrics and Gynecology, Unit of Reproductive Endocrinology, Medical School, Aristotle \\ University of Thessaloniki, 56403 Thessaloniki, Greece; dimitrios.goulis@gmail.com \\ 7 Department of Obstetrics and Gynecology, Medical School, National and Kapodistrian University of Athens, \\ 11526 Athens, Greece; ilambrinoudaki@med.uoa.gr \\ 8 Department of Cardiology, Hippokration Hospital, Medical School, National and Kapodistrian University of \\ Athens, 11526 Athens, Greece; gsiasos@med.uoa.gr \\ * Correspondence: s.a.paschou@gmail.com
}

Received: 5 September 2019; Accepted: 9 October 2019; Published: 14 October 2019

\begin{abstract}
The aim of this article is to review the literature regarding the relationship between vitamin D deficiency and cardiovascular disease (CVD) and its modification in the presence of obesity. Despite the strong association between vitamin D status and cardiovascular outcomes, vitamin D supplementation trials in the general population have failed to decrease the incidence of cardiovascular events and mortality. A comprehensive study of the published literature and a comparison with experimental data lead to the conclusion that obesity, due to its high prevalence and strong association with both vitamin D deficiency and CVD, may act as a critical confounder, which is responsible for the different results on this association. Adoption of a vitamin D preventive supplementation strategy for CVD is unlikely to yield any benefit to the general population. However, it might be particularly useful in obese adults with increased risk for CVD.
\end{abstract}

Keywords: vitamin D; obesity; cardiovascular disease; atherosclerosis

\section{Introduction}

Vitamin D is a lipid-soluble secosteroid hormone that was initially described as a crucial mediator of calcium homeostasis [1]. In humans, it is mainly synthesized in the skin, and its formation is catalyzed by ultraviolet B irradiation. After its formation, vitamin D needs to be transformed into its active form, 1,25 dihydroxy vitamin $\mathrm{D}$ [1,25(OH)2D], with 25-hydroxy-vitamin $\mathrm{D}[25(\mathrm{OH}) \mathrm{D}]$ being the most abundant form and thus the most frequently indicator used to assess vitamin $\mathrm{D}$ concentrations. While, initially, the interest in vitamin D was focused on mineral distribution and bone health, it was soon discovered that its receptors are expressed in many different tissues, which thus raises the probability of vitamin D implication in other conditions. Vitamin D concentrations correlate well with many medical conditions, most notably, cardiovascular disease (CVD) [2,3], and with the incidence of colorectal carcinoma [4] and multiple sclerosis [5,6]. Another important finding in this direction is the 
discovery that a substantial proportion of the population is deficient in vitamin $\mathrm{D}$, which has been defined as $25(\mathrm{OH}) \mathrm{D}$ concentration $<20 \mathrm{ng} / \mathrm{mL}(<50 \mathrm{nmol} / \mathrm{L})$ [7], while the concentration of $30 \mathrm{ng} / \mathrm{mL}$ has been recommended as a threshold [8]. The average recommended uptake is $5-20 \mu \mathrm{g} /$ day [9]. As per both definitions and irrespectively of the country studied, deficiency affects a great proportion of the population, with an estimated prevalence of 34-66\% [10], while there are reports of deficiency even in $94 \%$ of some population groups [11,12].

At the same time, the prevalence of obesity is rapidly increasing globally. According to the most recent report, 603.7 million adults are obese and approximately 4 million deaths annually should be attributed to obesity and its complications, with the majority of them being due to cardiovascular causes [13]. In the general population, CVD is also the leading cause of mortality, claiming 17.92 million deaths annually [14]. The understanding of the economic and public health benefit that would be yielded by prevention programs has shifted the interest towards interventions for primary prevention of CVD [15-17]. This review aims to assess the role of vitamin D in the development of CVD and discuss the impact of obesity as a possible explanation for the discrepancy between retrospective studies and randomized trials.

\section{Links between Vitamin D Status and Cardiovascular Disease}

\subsection{Early Evidence from Association Studies and Experimental Data}

Over the last decade, it was concluded that patients with coronary artery disease have decreased concentrations of vitamin D [18] and also that patients with decreased concentrations of vitamin D have elevated risk for major adverse cardiovascular events (MACE) [19]. The deleterious effects of vitamin D deficiency at this point were shown to be independent of other vascular comorbidities as hypertension and smoking [20]. Several meta-analyses that have been conducted demonstrate an inverse relationship between vitamin D concentrations and cardiovascular mortality [21], which was independent of the origin of the participants, season of the measurement, and patient's sex [22]. Moreover, vitamin D deficiency was associated with a decrease of high-density lipoprotein concentration and an increase of low-density lipoprotein (LDL) concentration compared to patients with optimal measurements (134.0 to 131.3, $p<0.001$ ) [23]. Experimental data enhanced this concept, as it was demonstrated that vitamin D controls cholesterol concentrations through changes in the activity levels of cytochrome P450 CYP27A1 and induction of cell cycle arrest in the recruited macrophages [24]. Moreover, through direct interaction with nuclear factor kappa beta (NFkB) [25], vitamin D deficiency triggered inflammation both in epicardial fat [25] and in vascular wall, further augmenting the inflammatory response that has been deemed as detrimental for the progression of coronary artery disease and the fragility of the atheroma [26]. At the level of the arterioles, vitamin D concentrations affect the contractility of the muscular layer, and its deficiency increases vascular rigidity [27]. Mice that were fed an atherogenic diet that was deficient in vitamin D demonstrated increased vascular calcification [28]. Regarding the myocardium, Sunbul et al. demonstrated that baseline vitamin D concentrations correlate with echocardiography-measured epicardial fat thickness and global longitudinal strain of the left ventricle, and both parameters correlate well with future history of CVD [29]. At the molecular level, vitamin D was demonstrated to alleviate oxidative stress in the myocardium of animals that were fed a high-fat diet [30] and the adverse effects of advanced glycation end products in the vascular wall of diabetic rats [31]. Thus, a plausible hypothesis has been developed, linking vitamin D deficiency with the pathogenesis of CVD and posing vitamin $\mathrm{D}$ as an ideal candidate for the primary prevention treatment of CVDs [32].

\subsection{Prospective Studies and Randomized Clinical Trials}

Unfortunately, the anticipation that was created by the encouraging results of laboratory and association studies has fallen short. Several meta-analyses were conducted but did not show any difference between patients treated with vitamin D and those who were not [33]. Postmenopausal 
women $(n=36,282)$ from the Women's Health Initiative participated in a prospective randomized clinical trial to assess the effects of calcium and vitamin D supplementation. When assessing cardiovascular outcomes, no difference was uncovered in MACEs between women that were treated with vitamin D and those that were treated with placebo [34]. A post-hoc analysis, 11 years after termination of the study, also did not confirm benefits from vitamin D supplementation regarding CVD [35]. However, only prospective randomized clinical trials could effectively assess whether the vitamin D hypothesis is right or wrong [33]. A prospective clinical trial in New Zealand that involved 5108 participants and assessed the impact of vitamin D supplementation in the primary prevention of MACE, arrhythmia, and vein thrombosis did not show any difference in the incidence of these disorders, which was similar in both placebo and intervention arms. Only $25 \%$ of the participants were vitamin D-deficient, and only $2 \%$ had a $25(\mathrm{OH}) \mathrm{D}$ concentration $<10 \mathrm{ng} / \mathrm{ml}$ [36]. The vitamin D and Omega-3 Trial (VITAL) was designed to assess whether vitamin D supplementation could represent an effective mean of primary prevention of both cancer and CVD. Despite the large study population of 25,871 participants and the adequate dosing of 2.000 international units (IU) of vitamin D, the trial did not demonstrate any difference in outcomes between the two treatment groups in terms of both mortality and MACE. That was unchanged even after adjusting for confounding risk factors, including body mass index (BMI); the groups, however, were divided in those with BMI $<27.1$ and those with BMI $\geq 27.1 \mathrm{~kg} / \mathrm{m}^{2}$ [37]. Last but not least, in a trial assessing a population of adult diabetics, vitamin $\mathrm{D}$ supplementation did not ameliorate other vascular comorbidities such as blood pressure, with only modest changes in pulse wave velocity [38], and the same outcomes were confirmed from another study in Europe in which patients diagnosed with hypertension were treated with vitamin $\mathrm{D}$ but did not show any improvement in their blood pressure [39]. In a large study involving 68,132 post-menopausal women, supplementation of calcium and vitamin D did not result in any change in low-density lipoprotein concentration, which remained unchanged after adjusting for dosing [40]. Even when shifting from the general population to frail adults, the results are still not encouraging, as all-cause mortality in patients with heart failure was not affected by vitamin D supplementation. Moreover, the initial vitamin D measurement did not have any effect on death rates [41]. In patients with metabolic syndrome, vitamin D supplementation could not reverse LDL-cholesterol concentrations, hemoglobin $(\mathrm{Hb}) \mathrm{A} 1 \mathrm{c}$, and diastolic blood pressure [42].

\section{The Inter-Relationship between Obesity, Vitamin D, and Cardiovascular Health}

\subsection{Effects of Obesity on Vitamin D Deficiency and Cardiovascular Disease}

Could these risk factors act as confounders and be the reason for the failure of vitamin $\mathrm{D}$ in the prevention of CVD despite the reports from observational studies? It is well known that confounders are a paramount limitation in cross-sectional analyses and limit their validity [43]. Results from observational prospective longitudinal studies indicate obesity as a probable confounder. The analysis of the serum from 1484 children in Denmark demonstrated an odds ratio (OR) of 3.41 for vitamin D deficiency in obese individuals and an inverse relationship between vitamin $\mathrm{D}$ concentrations and BMI [44]. The relationship was even more profound in infants, as 70.9 to $88.4 \%$ of obese children aged 1 to 5 years in Poland were demonstrated to have either suboptimal or deficient vitamin D concentrations [45]. In adults, the association is also significant, yet of lesser magnitude, with obese adults of Mexican descent presenting a $78 \%$ increased risk for developing vitamin D deficiency compared to individuals with normal BMI [46]. In the United States, obesity was recognized as an important risk factor for the development of vitamin deficiency, as obese patients had a $58 \%$ probability of developing it, compared to $33 \%$ for individuals with normal weight [47]. In Europe, a cross-sectional analysis of the adult population in the city of Porto demonstrated that obese individuals had lower vitamin D concentrations independently of the season in which the measurement took place [48]. In a Serbian study, $88 \%$ of obese individuals had vitamin D deficiency compared with only $31 \%$ of 
controls [49]. Similar results were reported in Asian populations, as body fat had a negative association with serum vitamin D concentrations [50,51].

On the other hand, obesity also increases the incidence of CVD in adults substantially. Peak BMI has been demonstrated to be detrimental for survival in a prospective study that included 457,785 men and 588,369 women that were followed up for 14 years [52]. In a large retrospective study that was assembled in the United Kingdom and consisted of 3.5 million adults, obesity was associated with a $49 \%$ increase of the risk for coronary heart disease in 5.4 years of follow-up [53]. Non-smoking adults were found to have a dose-dependent increase in cardiovascular mortality compared to their peers with normal weight (hazard ratio 2.04, 3.05, and 4.42 for BMI of 30-34.9, 35-39.9, and 40-49.9 kg/ $\mathrm{m}^{2}$, respectively) [54]. Obese adults were demonstrated to have progression of atherosclerotic lesions even after receiving optimal medical treatment with statins for hyperlipidemia [55]. The presence of obesity along with diabetes mellitus and hypertension resulted in an increase in the incidence of both mortality and heart failure, with expected benefit from prevention of obesity [56]. Moreover, other indicators of excessive adiposity such as the visceral adiposity index have also been identified as independent predictors of 10-year risk of CVD in a prospective clinical study that involved 3042 Greek adults [57]. Apart from the outcomes, obesity also markedly affects other conventional cardiovascular risk factors, including systolic blood pressure [58] as well as oxidized LDL-cholesterol concentrations [59]. Moreover, the prevalence of diabetes mellitus is markedly increased in obese adults compared to individuals with normal BMI, and its incidence strongly correlates with the incidence of obesity in the population [60].

\subsection{Pathophysiology of Vitamin D Deficiency in Obesity}

The pathophysiology link between obesity and serum vitamin D concentrations is complex, yet well established. Obese patients have decreased serum 25(OH)D concentrations compared with healthy controls after oral supplementation of vitamin D [61]. However, the peak levels just after ingestion was the same between the two groups; this formulated the hypothesis that vitamin $\mathrm{D}$ is stored in the adipose tissue and, thus, its bioavailability for conversion to its active metabolites is lost [61]. In agreement with this notion, animal studies showed that $25(\mathrm{OH}) \mathrm{D}$ was stored for $33 \%$ in fat and for $20 \%$ in muscle [62]. Thus, muscle might act as another reservoir of vitamin D in obese humans, who have been documented to have an adaptive increase in lean body mass [63,64]. On the other hand, Jung et al. [65] documented an increase of 1,25(OH)2D in mice that were fed a high-fat diet, which could be attributed to increased mRNA levels of renal 1-hydroxylase. In the same experiment, the authors demonstrated that the adipose tissue of these animals also had increased levels of vitamin D receptor, further enhancing the hypothesis of storage in adipose tissue. In another mouse study, [66] obese animals that were fed a high-fat diet had similar vitamin $\mathrm{D}$ and $25(\mathrm{OH}) \mathrm{D}$ concentrations but decreased plasma concentration of both $25(\mathrm{OH}) \mathrm{D}$ free form and vitamin D compared with controls. In this study, renal 1-hydroxylase concentrations were decreased in the obese animals [66]. Perhaps, the reason for the different outcomes might be the composition of the fatty acids, as it was recently demonstrated that renal 1-hydroxylase expression is induced by mono-unsaturated fatty acids but inhibited by saturated fatty acids. Thus, it is not only the amount of consumed fat but also the composition of fatty acids in the adipose tissue that play an important role in the response of hydroxylases and in determining the availability of the active form of vitamin D [67]. The increased expression of renal 1-hydroxylase was abolished after a change from high- to low-fat diet in the animals, consolidating the causal association between adiposity and $25(\mathrm{OH}) \mathrm{D}$ concentrations [65].

Regarding endogenously synthesized vitamin D, an increase in BMI results in a decrease of cholecalciferol synthesis for the same exposure to ultraviolet B irradiation, provided that the other controlling factors, such as the surface of the exposed area, remain stable [68]. Despite this observation, obese individuals had lower sunlight exposure and decreased outdoor activity, which further decreased the biosynthesis of vitamin D [69]. Finally, obese patients have increased risk for hepatic steatosis and non-alcoholic fatty liver disease, which downregulate the formation of 25(OH)D in the liver [70]. 
In a cross-sectional study, patients with non-alcoholic fatty liver disease had high risk of vitamin D deficiency, which was positively correlated with the severity of the disease [71].

\subsection{Effects of Vitamin D Deficiency on Cardiovascular Health in Obese and Non-Obese Populations}

The above-presented evidence should not lead to the conclusion that vitamin D deficiency does not have detrimental consequences for vascular health. However, both the prevalence of vitamin D deficiency and its effects are exponentially increased in obese people, leading to the question of choosing the correct population. In obese rats, a vitamin D-deficient diet led to the suppression of beta-oxidation and the accumulation of macrophages due to adipose tissue inflammation [72]. In a rodent model of induced hypertension, treatment with vitamin $\mathrm{D}$ ameliorated the outcomes and resulted in a decrease in blood pressure [73]. In another rodent model, deficiency of vitamin D resulted in exacerbation of the hypertension phenotype, fostering the association between vitamin $\mathrm{D}$ and blood pressure regulation [74]. Treatment with vitamin D resulted in major differences in the degree of vascular inflammation in a porcine model of hypercholesterolemia that underwent primary coronary intervention [75]. In obese and overweight humans, vitamin D supplementation resulted in the decrease of urinary isoprostane and of the vascular augmentation index, underlining prospective benefits for vascular health and oxidative stress [76]. However, in all these models (Table 1), the animals were not healthy but had another prominent cardiovascular risk factor. In all vitamin D supplementation studies, the target was the general population. The most definitive answer was provided by a meta-analysis of 42,024 adults pooled from 21 cohort studies. The authors performed a bi-directional Mendelian randomization analysis in which they compared the incidence of vitamin D deficiency in haplotypes associated with obesity to the incidence of obesity in haplotypes associated with vitamin $\mathrm{D}$ deficiency. The results indicate that, when correcting for environmental confounders, there is a strong negative correlation between BMI and vitamin D status and that obese adults are expected to have vitamin $\mathrm{D}$ concentrations $<50 \mathrm{nmol} / \mathrm{mg}$, hence explaining the extreme incidence of vitamin $\mathrm{D}$ deficiency in obese adults [77]. The paradigm of differential effects of vitamin D deficiency according to the general health of the population is not a novel concept. While vitamin D concentrations have been found to correlate with oxidative stress both in obese children [78] and in elderly diabetic individuals [79], when measured in a healthy population, the association was either very weak or non-existent [80].

Table 1. Effects of Vitamin D on vascular health in various studies of animal models and clinical research.

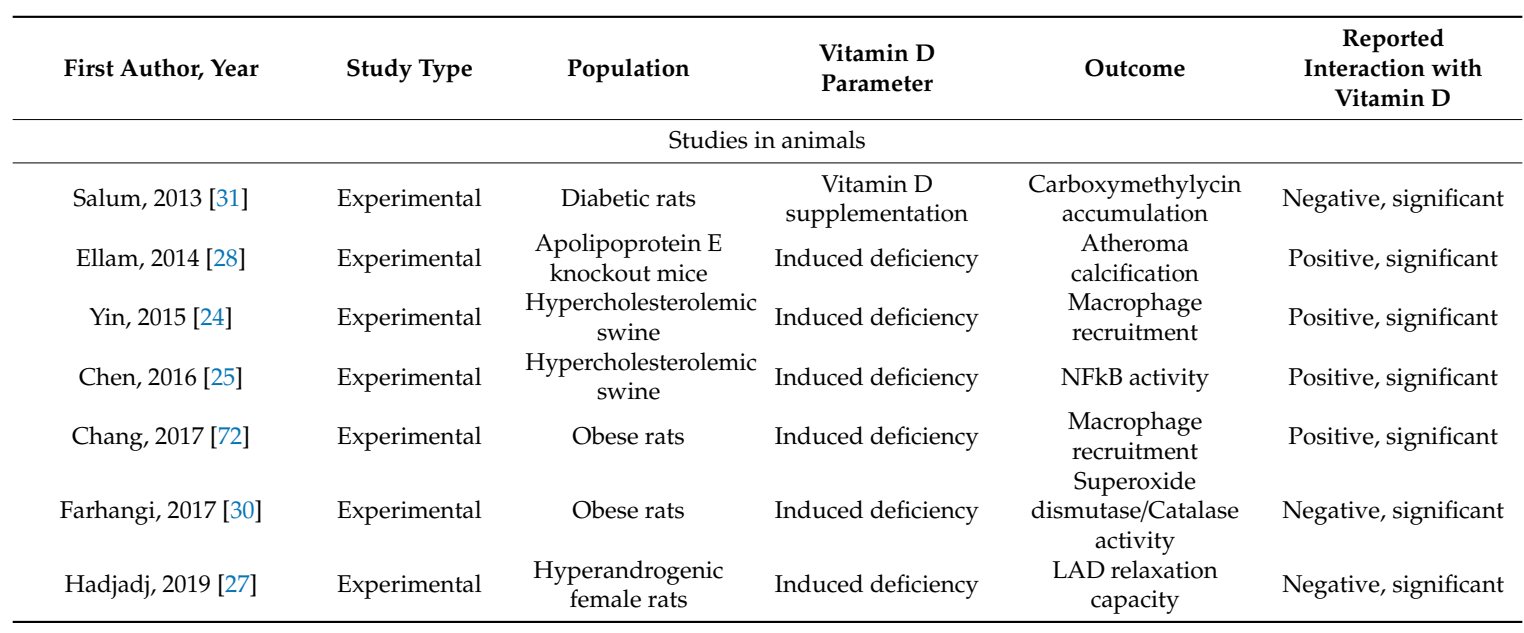


Table 1. Cont

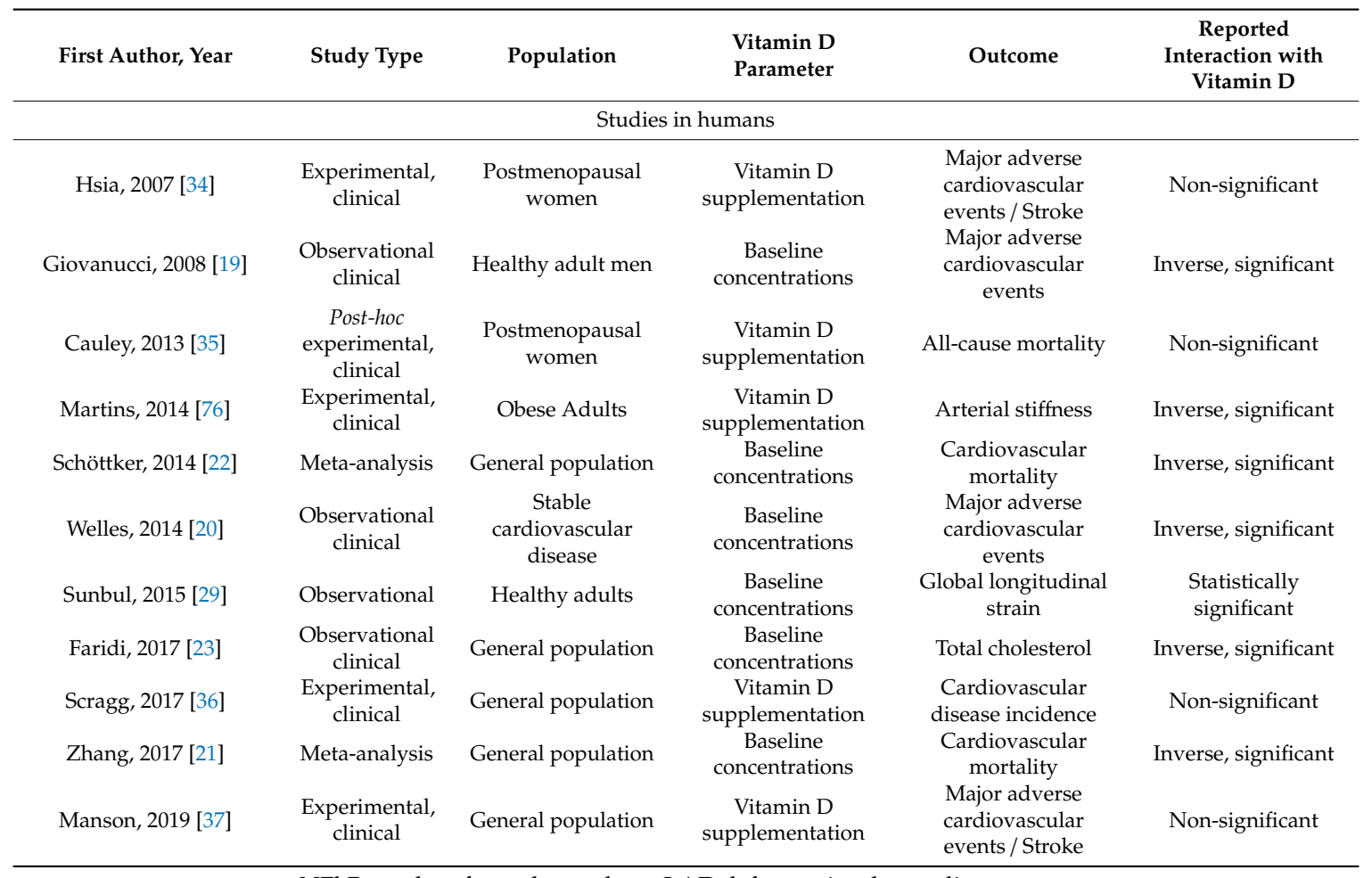

NFkB: nuclear factor kappa beta; LAD: left anterior descending artery.

\section{Future Perspectives}

Consolidating these findings, we can speculate that CVD occurs in response to an underlying condition which is then further exacerbated by vitamin D deficiency, most notably due to the lack of its countereffect on oxidative stress (Figure 1). There is strong evidence to support that obesity could well constitute this underlying confounder due to its high prevalence and its detrimental effect on both vitamin $\mathrm{D}$ status and cardiovascular mortality. Therefore, we could think that the adoption of the general population as the target for prevention of CVD with vitamin D supplementation was the probable cause for the failure of trials in demonstrating benefit of vitamin D supplementation for the prevention of CVD and not necessarily a lack of effects of vitamin $\mathrm{D}$ in the cardiovascular system. Only a prospective clinical trial including either patients with a particular risk factor or a population with increased general cardiovascular risk could definitively answer whether prevention of CVD was a mistargeted intervention or a misconception.

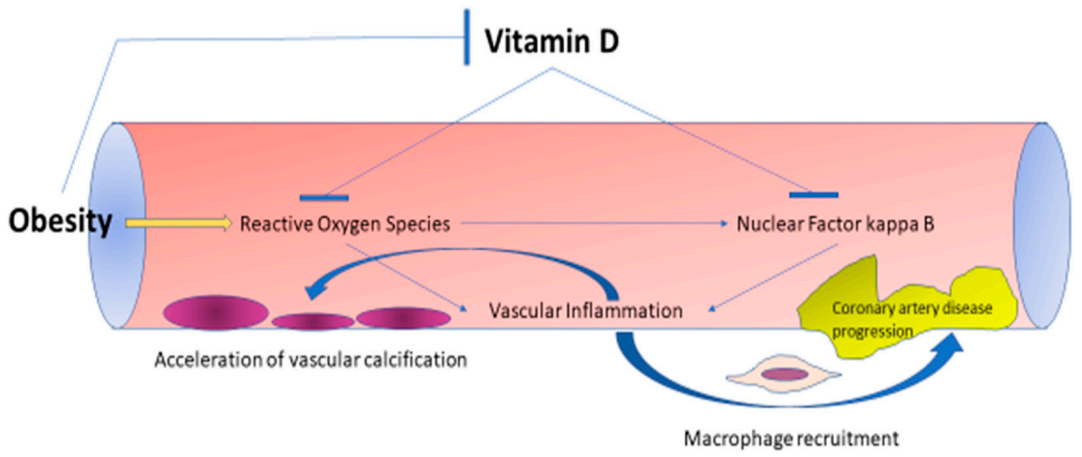

Figure 1. Proposed effects of vitamin D on obesity-related atherosclerotic progression. Vitamin D prevents further macrophage recruitment in atherosclerotic lesions and decreases vascular inflammation through inhibition of nuclear factor kappa B and decoying of reactive oxygen species. Obesity alleviates the beneficial effects of vitamin D on the vasculature by decreasing vitamin D bioavailability and augmenting the production of reactive oxygen species. 
Author Contributions: S.A.P. and G.S. designed the article. S.A.P. and M.K. searched the literature and wrote the initial draft. I.P.N., M.S., E.K., D.G.G., I.L. and G.S. revised the manuscript for important intellectual content. All authors approved the final version of the article.

Funding: This research received no external funding.

Conflicts of Interest: The authors declare no conflict of interest.

\section{References}

1. Cano, A.; Chedraui, P.; Goulis, D.G.; Lopes, P.; Mishra, G.; Mueck, A.; Senturk, L.M.; Simoncini, T.; Stevenson, J.C.; Stute, P.; et al. Calcium in the prevention of postmenopausal osteoporosis: EMAS clinical guide. Maturitas 2018, 107, 7-12. [CrossRef] [PubMed]

2. Apostolakis, M.; Armeni, E.; Bakas, P.; Lambrinoudaki, I. Vitamin D and cardiovascular disease. Maturitas 2018, 115, 1-22. [CrossRef] [PubMed]

3. Anagnostis, P.; Paschou, S.A.; Goulis, D.G. Vitamin D Supplementation and Cardiovascular Disease Risk. JAMA Cardiol. 2017, 2, 1281-1282. [CrossRef] [PubMed]

4. Andersen, S.W.; Shu, X.O.; Cai, Q.; Khankari, N.K.; Steinwandel, M.D.; Jurutka, P.W.; Blot, W.J.; Zheng, W. Total and Free Circulating Vitamin D and Vitamin D-Binding Protein in Relation to Colorectal Cancer Risk in a Prospective Study of African Americans. Cancer Epidemiol Biomarkers Prev. 2017, 26, 1242-1247. [CrossRef]

5. Miclea, A.; Miclea, M.; Pistor, M.; Hoepner, A.; Chan, A.; Hoepner, R. Vitamin D supplementation differentially affects seasonal multiple sclerosis disease activity. Brain Behav. 2017, 7, e00761. [CrossRef]

6. Lambrinoudaki, I.; Patikas, E.; Kaparos, G.; Armeni, E.; Rizos, D.; Thoda, P.; Alexandrou, A.; Antoniou, A.; Tsivgoulis, G.; Gatzonis, S.; et al. Vitamin D receptor Bsm1 polymorphism, calcium metabolism and bone mineral density in patients with multiple sclerosis: A pilot study. Neurol. Sci. 2013, 34, 1433-1439. [CrossRef]

7. Ross, A.C.; Manson, J.E.; Abrams, S.A.; Aloia, J.F.; Brannon, P.M.; Clinton, S.K.; Durazo-Arvizu, R.A.; Gallagher, J.C.; Gallo, R.L.; Jones, G.; et al. The 2011 report on dietary reference intakes for calcium and vitamin D from the Institute of Medicine: What clinicians need to know. J. Clin. Endocrinol. Metab. 2011, 96, 53-58. [CrossRef]

8. Heaney, R.P.; Holick, M.F. Why the IOM recommendations for vitamin D are deficient. J. Bone Min. Res. 2011, 26, 455-457. [CrossRef]

9. Cashman, K.D.; Ritz, C.; Kiely, M.; Collaborators, O. Improved Dietary Guidelines for Vitamin D: Application of Individual Participant Data (IPD)-Level Meta-Regression Analyses. Nutrients 2017, 9, 469. [CrossRef]

10. Roth, D.E.; Abrams, S.A.; Aloia, J.; Bergeron, G.; Bourassa, M.W.; Brown, K.H.; Calvo, M.S.; Cashman, K.D.; Combs, G.; De-Regil, L.M.; et al. Global prevalence and disease burden of vitamin D deficiency: A roadmap for action in low- and middle-income countries. Ann. N. Y. Acad. Sci. 2018, 1430, 44-79. [CrossRef]

11. Pilz, S.; Dobnig, H.; Tomaschitz, A.; Kienreich, K.; Meinitzer, A.; Friedl, C.; Wagner, D.; Piswanger-Sölkner, C.; März, W.; Fahrleitner-Pammer, A. Low 25-hydroxyvitamin D is associated with increased mortality in female nursing home residents. J. Clin. Endocrinol. Metab. 2012, 97, E653-E657. [CrossRef] [PubMed]

12. Karras, S.; Paschou, S.A.; Kandaraki, E.; Anagnostis, P.; Annweiler, C.; Tarlatzis, B.C.; Hollis, B.W.; Grant, W.B.; Goulis, D.G. Hypovitaminosis D in pregnancy in the Mediterranean region: A systematic review. Eur. J. Clin. Nutr. 2016, 70, 979-986. [CrossRef] [PubMed]

13. Afshin, A.; Forouzanfar, M.H.; Reitsma, M.B.; Sur, P.; Estep, K.; Lee, A.; Marczak, L.; Mokdad, A.H.; Moradi-Lakeh, M.; Naghavi, M.; et al. Health Effects of Overweight and Obesity in 195 Countries over 25 Years. N. Engl. J. Med. 2017, 377, 13-27. [PubMed]

14. Roth, G.A.; Johnson, C.; Abajobir, A.; Abd-Allah, F.; Abera, S.F.; Abyu, G.; Ahmed, M.; Aksut, B.; Alam, T.; Alam, K.; et al. Global, Regional, and National Burden of Cardiovascular Diseases for 10 Causes, 1990 to 2015. J. Am. Coll. Cardiol. 2017, 70, 1-25. [CrossRef] [PubMed]

15. Piepoli, M.F.; Hoes, A.W.; Agewall, S.; Albus, C.; Brotons, C.; Catapano, A.L.; Cooney, M.T.; Corra, U.; Cosyns, B.; Deaton, C.; et al. 2016 European Guidelines on cardiovascular disease prevention in clinical practice: The Sixth Joint Task Force of the European Society of Cardiology and Other Societies on Cardiovascular Disease Prevention in Clinical Practice. Eur. Heart J. 2016, 37, 2315-2381. [CrossRef]

16. Mason, H.; Shoaibi, A.; Ghandour, R.; O’Flaherty, M.; Capewell, S.; Khatib, R.; Jabr, S.; Unal, B.; Sözmen, K.; Arfa, C.; et al. A cost effectiveness analysis of salt reduction policies to reduce coronary heart disease in four Eastern Mediterranean countries. PLoS ONE 2014, 9, e84445. [CrossRef] 
17. O'Keeffe, C.; Kabir, Z.; O’Flaherty, M.; Walton, J.; Capewell, S.; Perry, I.J. Modelling the impact of specific food policy options on coronary heart disease and stroke deaths in Ireland. BMJ Open 2013, 3, e002837. [CrossRef]

18. Siasos, G.; Tousoulis, D.; Oikonomou, E.; Maniatis, K.; Kioufis, S.; Kokkou, E.; Vavuranakis, M.; Zaromitidou, M.; Kassi, E.; Miliou, A.; et al. Vitamin D3, D2 and arterial wall properties in coronary artery disease. Curr. Pharm. Des. 2014, 20, 5914-5918. [CrossRef]

19. Giovannucci, E.; Liu, Y.; Hollis, B.W.; Rimm, E.B. 25-hydroxyvitamin D and risk of myocardial infarction in men: A prospective study. Arch. Intern. Med. 2008, 168, 1174-1180. [CrossRef]

20. Welles, C.C.; Whooley, M.A.; Karumanchi, S.A.; Hod, T.; Thadhani, R.; Berg, A.H.; Ix, J.H.; Mukamal, K.J. Vitamin D deficiency and cardiovascular events in patients with coronary heart disease: Data from the Heart and Soul Study. Am. J. Epidemiol. 2014, 179, 1279-1287. [CrossRef]

21. Zhang, R.; Li, B.; Gao, X.; Tian, R.; Pan, Y.; Jiang, Y.; Gu, H.; Wang, Y.; Wang, Y.; Liu, G. Serum 25-hydroxyvitamin $\mathrm{D}$ and the risk of cardiovascular disease: Dose-response meta-analysis of prospective studies. Am. J. Clin. Nutr. 2017, 105, 810-819. [CrossRef] [PubMed]

22. Schöttker, B.; Jorde, R.; Peasey, A.; Thorand, B.; Jansen, E.H.; de Groot, L.; Streppel, M.; Gardiner, J.; Ordóñez-Mena, J.M.; Perna, L.; et al. Vitamin D and mortality: Meta-analysis of individual participant data from a large consortium of cohort studies from Europe and the United States. BMJ 2014, 348, g3656. [CrossRef] [PubMed]

23. Faridi, K.F.; Zhao, D.; Martin, S.S.; Lupton, J.R.; Jones, S.R.; Guallar, E.; Ballantyne, C.M.; Lutsey, P.L.; Michos, E.D. Serum vitamin D and change in lipid levels over 5 y: The Atherosclerosis Risk in Communities study. Nutrition 2017, 38, 85-93. [CrossRef]

24. Yin, K.; You, Y.; Swier, V.; Tang, L.; Radwan, M.M.; Pandya, A.N.; Agrawal, D.K. Vitamin D Protects Against Atherosclerosis via Regulation of Cholesterol Efflux and Macrophage Polarization in Hypercholesterolemic Swine. Arterioscler. Thromb. Vasc. Biol. 2015, 35, 2432-2442. [CrossRef] [PubMed]

25. Chen, S.; Swier, V.J.; Boosani, C.S.; Radwan, M.M.; Agrawal, D.K. Vitamin D Deficiency Accelerates Coronary Artery Disease Progression in Swine. Arterioscler. Thromb. Vasc. Biol. 2016, 36, 1651-1659. [CrossRef] [PubMed]

26. Antonopoulos, A.S.; Sanna, F.; Sabharwal, N.; Thomas, S.; Oikonomou, E.K.; Herdman, L.; Margaritis, M.; Shirodaria, C.; Kampoli, A.M.; Akoumianakis, I.; et al. Detecting human coronary inflammation by imaging perivascular fat. Sci. Transl. Med. 2017, 9, eaal2658. [CrossRef]

27. Hadjadj, L.; Monori-Kiss, A.; Horváth, E.M.; Heinzlmann, A.; Magyar, A.; Sziva, R.E.; Miklós, Z.; Pál, É.; Gál, J.; Szabó, I.; et al. Geometric, elastic and contractile-relaxation changes in coronary arterioles induced by Vitamin D deficiency in normal and hyperandrogenic female rats. Microvasc. Res. 2019, 122, 78-84. [CrossRef]

28. Ellam, T.; Hameed, A.; ul Haque, R.; Muthana, M.; Wilkie, M.; Francis, S.E.; Chico, T.J. Vitamin D deficiency and exogenous vitamin $\mathrm{D}$ excess similarly increase diffuse atherosclerotic calcification in apolipoprotein $\mathrm{E}$ knockout mice. PLoS ONE 2014, 9, e88767. [CrossRef]

29. Sunbul, M.; Bozbay, M.; Mammadov, C.; Cincin, A.; Atas, H.; Ozsenel, E.B.; Sari, I.; Basaran, Y. Effect of vitamin D deficiency and supplementation on myocardial deformation parameters and epicardial fat thickness in patients free of cardiovascular risk. Int. J. Cardiovasc. Imaging 2015, 31, 765-772. [CrossRef]

30. Farhangi, M.A.; Nameni, G.; Hajiluian, G.; Mesgari-Abbasi, M. Cardiac tissue oxidative stress and inflammation after vitamin D administrations in high fat- diet induced obese rats. BMC Cardiovasc. Disord. 2017, 17, 161. [CrossRef]

31. Salum, E.; Kals, J.; Kampus, P.; Salum, T.; Zilmer, K.; Aunapuu, M.; Arend, A.; Eha, J.; Zilmer, M. Vitamin D reduces deposition of advanced glycation end-products in the aortic wall and systemic oxidative stress in diabetic rats. Diabetes Res. Clin. Pract. 2013, 100, 243-249. [CrossRef] [PubMed]

32. Holick, M.F. Sunlight and vitamin D for bone health and prevention of autoimmune diseases, cancers, and cardiovascular disease. Am. J. Clin. Nutr. 2004, 80, 1678S-1688S. [CrossRef] [PubMed]

33. Al Mheid, I.; Quyyumi, A.A. Vitamin D and Cardiovascular Disease: Controversy Unresolved. J. Am. Coll. Cardiol. 2017, 70, 89-100. [CrossRef] [PubMed]

34. Hsia, J.; Heiss, G.; Ren, H.; Allison, M.; Dolan, N.C.; Greenland, P.; Heckbert, S.R.; Johnson, K.C.; Manson, J.E.; Sidney, S.; et al. Calcium/vitamin D supplementation and cardiovascular events. Circulation 2007, 115, 846-854. [CrossRef] [PubMed] 
35. Cauley, J.A.; Chlebowski, R.T.; Wactawski-Wende, J.; Robbins, J.A.; Rodabough, R.J.; Chen, Z.; Johnson, K.C.; O'Sullivan, M.J.; Jackson, R.D.; Manson, J.E. Calcium plus vitamin D supplementation and health outcomes five years after active intervention ended: The Women's Health Initiative. J. Women's Health 2013, 22, 915-929. [CrossRef]

36. Scragg, R.; Stewart, A.W.; Waayer, D.; Lawes, C.M.; Toop, L.; Sluyter, J.; Murphy, J.; Khaw, K.T.; Camargo, C.A. Effect of Monthly High-Dose Vitamin D Supplementation on Cardiovascular Disease in the Vitamin D Assessment Study: A Randomized Clinical Trial. JAMA Cardiol. 2017, 2, 608-616. [CrossRef]

37. Manson, J.E.; Cook, N.R.; Lee, I.M.; Christen, W.; Bassuk, S.S.; Mora, S.; Gibson, H.; Gordon, D.; Copeland, T.; D'Agostino, D.; et al. Vitamin D Supplements and Prevention of Cancer and Cardiovascular Disease. N. Engl. J. Med. 2019, 380, 33-44. [CrossRef]

38. Forouhi, N.G.; Menon, R.K.; Sharp, S.J.; Mannan, N.; Timms, P.M.; Martineau, A.R.; Rickard, A.P.; Boucher, B.J.; Chowdhury, T.A.; Griffiths, C.J.; et al. Effects of vitamin D2 or D3 supplementation on glycaemic control and cardiometabolic risk among people at risk of type 2 diabetes: Results of a randomized double-blind placebo-controlled trial. Diabetes Obes. Metab. 2016, 18, 392-400. [CrossRef]

39. Pilz, S.; Gaksch, M.; Kienreich, K.; Grübler, M.; Verheyen, N.; Fahrleitner-Pammer, A.; Treiber, G.; Drechsler, C.; ó Hartaigh, B.; Obermayer-Pietsch, B.; et al. Effects of vitamin D on blood pressure and cardiovascular risk factors: A randomized controlled trial. Hypertension 2015, 65, 1195-1201. [CrossRef]

40. Schnatz, P.F.; Jiang, X.; Aragaki, A.K.; Nudy, M.; O’Sullivan, D.M.; Williams, M.; LeBlanc, E.S.; Martin, L.W.; Manson, J.E.; Shikany, J.M.; et al. Effects of Calcium, Vitamin D, and Hormone Therapy on Cardiovascular Disease Risk Factors in the Women's Health Initiative: A Randomized Controlled Trial. Obstet. Gynecol. 2017, 129, 121-129. [CrossRef]

41. Zittermann, A.; Ernst, J.B.; Prokop, S.; Fuchs, U.; Dreier, J.; Kuhn, J.; Knabbe, C.; Birschmann, I.; Schulz, U.; Berthold, H.K.; et al. Effect of vitamin D on all-cause mortality in heart failure (EVITA): A 3-year randomized clinical trial with 4000 IU vitamin D daily. Eur. Heart J. 2017, 38, 2279-2286. [CrossRef] [PubMed]

42. Makariou, S.E.; Elisaf, M.; Challa, A.; Tentolouris, N.; Liberopoulos, E.N. No effect of vitamin D supplementation on cardiovascular risk factors in subjects with metabolic syndrome: A pilot randomised study. Arch. Med. Sci. Atheroscler. Dis. 2017, 2, e52-e60. [CrossRef] [PubMed]

43. Jepsen, P.; Johnsen, S.P.; Gillman, M.W.; Sorensen, H.T. Interpretation of observational studies. Heart 2004, 90, 956-960. [CrossRef] [PubMed]

44. Plesner, J.L.; Dahl, M.; Fonvig, C.E.; Nielsen, T.R.H.; Kloppenborg, J.T.; Pedersen, O.; Hansen, T.; Holm, J.C. Obesity is associated with vitamin D deficiency in Danish children and adolescents. J. Pediatr. Endocrinol. Metab. 2018, 31, 53-61. [CrossRef] [PubMed]

45. Dylag, H.; Rowicka, G.; Strucinska, M.; Riahi, A. Assessment of vitamin D status in children aged 1-5 with simple obesity. Rocz. Panstw. Zakl. Hig. 2014, 65, 325-330.

46. Rontoyanni, V.G.; Avila, J.C.; Kaul, S.; Wong, R.; Veeranki, S.P. Association between Obesity and Serum 25(OH)D Concentrations in Older Mexican Adults. Nutrients 2017, 9, 97. [CrossRef]

47. Forrest, K.Y.Z.; Stuhldreher, W.L. Prevalence and correlates of vitamin D deficiency in US adults. Nutr. Res. 2011, 31, 48-54. [CrossRef]

48. Bettencourt, A.; Boleixa, D.; Reis, J.; Oliveira, J.C.; Mendonça, D.; Costa, P.P.; da Silva, B.M.; Marinho, A.; da Silva, A.M. Serum 25-hydroxyvitamin D levels in a healthy population from the North of Portugal. J. Steroid Biochem. Mol. Biol. 2018, 175, 97-101. [CrossRef]

49. Stokić, E.; Kupusinac, A.; Tomić-Naglić, D.; Zavišić, B.K.; Mitrović, M.; Smiljenić, D.; Soskić, S.; Isenović, E. Obesity and vitamin D deficiency: Trends to promote a more proatherogenic cardiometabolic risk profile. Angiology 2015, 66, 237-243. [CrossRef]

50. Fatima, S.S.; Farooq, S.; Tauni, M.A.; Irfan, O.; Alam, F. Effect of raised body fat on vitamin D, leptin and bone mass. J. Pak. Med. Assoc. 2015, 65, 1315-1319.

51. Shafinaz, I.S.; Moy, F.M. Vitamin D level and its association with adiposity among multi-ethnic adults in Kuala Lumpur, Malaysia: A cross sectional study. BMC Public Health 2016, 16, 232. [CrossRef] [PubMed]

52. Calle, E.E.; Thun, M.J.; Petrelli, J.M.; Rodriguez, C.; Heath, C.W.J. Body-mass index and mortality in a prospective cohort of U.S. adults. N. Engl. J. Med. 1999, 341, 1097-1105. [CrossRef] [PubMed]

53. Caleyachetty, R.; Thomas, G.N.; Toulis, K.A.; Mohammed, N.; Gokhale, K.M.; Balachandran, K.; Nirantharakumar, K. Metabolically Healthy Obese and Incident Cardiovascular Disease Events Among 3.5 Million Men and Women. J. Am. Coll. Cardiol. 2017, 70, 1429-1437. [CrossRef] [PubMed] 
54. Berrington de Gonzalez, A.; Hartge, P.; Cerhan, J.R.; Flint, A.J.; Hannan, L.; MacInnis, R.J.; Moore, S.C.; Tobias, G.S.; Anton-Culver, H.; Freeman, L.B.; et al. Body-mass index and mortality among 1.46 million white adults. N. Engl. J. Med. 2010, 363, 2211-2219. [CrossRef]

55. Sandfort, V.; Lai, S.; Ahlman, M.A.; Mallek, M.; Liu, S.; Sibley, C.T.; Turkbey, E.B.; Lima, J.A.; Bluemke, D.A. Obesity Is Associated with Progression of Atherosclerosis During Statin Treatment. J. Am. Heart Assoc. 2016, 5, e003621. [CrossRef]

56. Ahmad, F.S.; Ning, H.; Rich, J.D.; Yancy, C.W.; Lloyd-Jones, D.M.; Wilkins, J.T. Hypertension, Obesity, Diabetes, and Heart Failure-Free Survival: The Cardiovascular Disease Lifetime Risk Pooling Project. JACC Heart Fail. 2016, 4, 911-919. [CrossRef]

57. Kouli, G.M.; Panagiotakos, D.B.; Kyrou, I.; Georgousopoulou, E.N.; Chrysohoou, C.; Tsigos, C.; Tousoulis, D.; Pitsavos, C. Visceral adiposity index and 10-year cardiovascular disease incidence: The ATTICA study. Nutr. Metab. Cardiovasc. Dis. 2017, 27, 881-889. [CrossRef]

58. Araujo, J.; Severo, M.; Barros, H.; Ramos, E. Duration and degree of adiposity: Effect on cardiovascular risk factors at early adulthood. Int. J. Obes. 2017, 41, 1526-1530. [CrossRef]

59. Kelly, A.S.; Jacobs, D.R.J.; Sinaiko, A.R.; Moran, A.; Steffen, L.M.; Steinberger, J. Relation of circulating oxidized LDL to obesity and insulin resistance in children. Pediatr. Diabetes 2010, 11, 552-555. [CrossRef]

60. Geiss, L.S.; Kirtland, K.; Lin, J.; Shrestha, S.; Thompson, T.; Albright, A.; Gregg, E.W. Changes in diagnosed diabetes, obesity, and physical inactivity prevalence in US counties, 2004-2012. PLoS ONE 2017, 12, e0173428. [CrossRef]

61. Wortsman, J.; Matsuoka, L.Y.; Chen, T.C.; Lu, Z.; Holick, M.F. Decreased bioavailability of vitamin D in obesity. Am. J. Clin. Nutr. 2000, 72, 690-693. [CrossRef] [PubMed]

62. Mawer, E.B.; Backhouse, J.; Holman, C.A.; Lumb, G.A.; Stanbury, S.W. The distribution and storage of vitamin D and its metabolites in human tissues. Clin. Sci. 1972, 43, 413-431. [CrossRef] [PubMed]

63. Forbes, G.B.; Welle, S.L. Lean body mass in obesity. Int. J. Obes. 1983, 7, 99-107.

64. Cipriani, C.; Pepe, J.; Piemonte, S.; Colangelo, L.; Cilli, M.; Minisola, S. Vitamin d and its relationship with obesity and muscle. Int. J. Endocrinol. 2014, 2014, 841248. [CrossRef]

65. Jung, Y.S.; Wu, D.; Smith, D.; Meydani, S.N.; Han, S.N. Dysregulated 1,25-dihydroxyvitamin D levels in high-fat diet-induced obesity can be restored by changing to a lower-fat diet in mice. Nutr. Res. 2018, 53, 51-60. [CrossRef] [PubMed]

66. Bonnet, L.; Hachemi, M.A.; Karkeni, E.; Couturier, C.; Astier, J.; Defoort, C.; Svilar, L.; Martin, J.C.; Tourniaire, F.; Landrier, J.F. Diet induced obesity modifies vitamin D metabolism and adipose tissue storage in mice. J. Steroid Biochem. Mol. Biol. 2019, 185, 39-46. [CrossRef] [PubMed]

67. Wang, Y.; Buckendahl, P.; Sharma, K.; Miller, J.W.; Shapses, S.A. Expression of vitamin D hydroxylases and bone quality in obese mice consuming saturated or monounsaturated enriched high-fat diets. Nutr. Res. 2018, 60, 106-115. [CrossRef] [PubMed]

68. Osmancevic, A.; Gillstedt, M.; Landin-Wilhelmsen, K.; Larkö, A.M.W.; Larkö, O.; Holick, M.F.; Krogstad, A.L. Size of the exposed body surface area, skin erythema and body mass index predict skin production of vitamin D. J. Photochem. Photobiol. B 2015, 149, 224-229. [CrossRef] [PubMed]

69. Florez, H.; Martinez, R.; Chacra, W.; Strickman-Stein, N.; Levis, S. Outdoor exercise reduces the risk of hypovitaminosis D in the obese. J. Steroid Biochem. Mol. Biol. 2007, 103, 679-681. [CrossRef]

70. Targher, G.; Bertolini, L.; Scala, L.; Cigolini, M.; Zenari, L.; Falezza, G.; Arcaro, G. Associations between serum 25-hydroxyvitamin D3 concentrations and liver histology in patients with non-alcoholic fatty liver disease. Nutr. Metab. Cardiovasc. Dis. 2007, 17, 517-524. [CrossRef]

71. Liu, S.; Liu, Y.; Wan, B.; Zhang, H.; Wu, S.; Zhu, Z.; Lin, Y.; Wang, M.; Zhang, N.; Lin, S.; et al. Association between Vitamin D Status and Non-Alcoholic Fatty Liver Disease: A Population-Based Study. J. Nutr. Sci. Vitam. 2019, 65, 303-308. [CrossRef] [PubMed]

72. Chang, E.; Kim, Y. Vitamin D Insufficiency Exacerbates Adipose Tissue Macrophage Infiltration and Decreases AMPK/SIRT1 Activity in Obese Rats. Nutrients 2017, 9, 338. [CrossRef] [PubMed]

73. Shamardl, H.A.; El-Ashmony, S.M.; Kamel, H.F.; Fatani, S.H. Potential Cardiovascular and Renal Protective Effects of Vitamin D and Coenzyme Q10 in 1-NAME-Induced Hypertensive Rats. Am. J. Med. Sci. 2017, 354, 190-198. [CrossRef] [PubMed] 
74. Andersen, L.B.; Przybyl, L.; Haase, N.; von Versen-Höynck, F.; Qadri, F.; Jørgensen, J.S.; Sorensen, G.L.; Fruekilde, P.; Poglitsch, M.; Szijarto, I.; et al. Vitamin D depletion aggravates hypertension and target-organ damage. J. Am. Heart Assoc. 2015, 4, e001417. [CrossRef]

75. Gupta, G.K.; Agrawal, T.; Rai, V.; Del Core, M.G.; Hunter, W.J., 3rd; Agrawal, D.K. Vitamin D Supplementation Reduces Intimal Hyperplasia and Restenosis following Coronary Intervention in Atherosclerotic Swine. PLoS ONE 2016, 11, e0156857. [CrossRef]

76. Martins, D.; Meng, Y.X.; Tareen, N.; Artaza, J.; Lee, J.E.; Farodolu, C.; Gibbons, G.; Norris, K. The Effect of Short Term Vitamin D Supplementation on the Inflammatory and Oxidative Mediators of Arterial Stiffness. Health 2014, 6, 1503-1511. [CrossRef]

77. Vimaleswaran, K.S.; Berry, D.J.; Lu, C.; Tikkanen, E.; Pilz, S.; Hiraki, L.T.; Cooper, J.D.; Dastani, Z.; Li, R.; Houston, D.K.; et al. Causal relationship between obesity and vitamin D status: Bi-directional Mendelian randomization analysis of multiple cohorts. PLoS Med. 2013, 10, e1001383. [CrossRef]

78. Codoner-Franch, P.; Tavarez-Alonso, S.; Simo-Jorda, R.; Laporta-Martin, P.; Carratala-Calvo, A.; Alonso-Iglesias, E. Vitamin D status is linked to biomarkers of oxidative stress, inflammation, and endothelial activation in obese children. J. Pediatr. 2012, 161, 848-854. [CrossRef]

79. Gradinaru, D.; Borsa, C.; Ionescu, C.; Margina, D.; Prada, G.I.; Jansen, E. Vitamin D status and oxidative stress markers in the elderly with impaired fasting glucose and type 2 diabetes mellitus. Aging Clin. Exp. Res. 2012, 24, 595-602.

80. Wang, E.W.; Siu, P.M.; Pang, M.Y.; Woo, J.; Collins, A.R.; Benzie, I.F.F. Vitamin D deficiency, oxidative stress and antioxidant status: Only weak association seen in the absence of advanced age, obesity or pre-existing disease. Br. J. Nutr. 2017, 118, 11-16. [CrossRef]

(C) 2019 by the authors. Licensee MDPI, Basel, Switzerland. This article is an open access article distributed under the terms and conditions of the Creative Commons Attribution (CC BY) license (http://creativecommons.org/licenses/by/4.0/). 